Прегледни чланак

$378.2: 34(439)$

doi:10.5937/zrpfns50-12688

Tamás Nótári, Ph.D., Associate Professor

Sapientia University, Cluj-Napoca

Department of Law

tamasnotari@yahoo.de

\title{
THE HISTORY OF ACADEMIC DEGREES AND TITLES IN JURISPRUDENCE IN HUNGARY
}

\begin{abstract}
In this paper we survey the system of academic degrees and important academic titles used in Hungary in the mirror of their historical development - as appropriate from the aspect of jurisprudence, omitting scientific titles that fall outside this field. First, we examine the requirements and statutory conditions of becoming a university professor (ordinary and extraordinary university professor) and university private professor (Privatdozent) in the period from Maria Theresa's Ratio educationis, i.e., 1777 to 1950. After that, we present the introduction, regulations of the academic degrees introduced in 1950 and 1951 following Soviet patterns: the candidate of sciences and doctor of sciences degrees and the rules of obtaining them as well as the system of scientific and researcher classification still used today. After the historical survey, we analyse the regulation of academic degrees and titles after the change of regime on the basis of statutory and institutional regulations. As part of that, we survey the system of requirements of obtaining the doctoral (PhD) degree, the requirements of habilitation as scientific qualification, the rules of winning the doctor of the Magyar Tudományos Akadémia (MTA) [Hungarian Academy of Sciences $(H A S)$ ] title replacing the doctor of sciences degree and the conditions of becoming an ordinary and corresponding member of the Academy.
\end{abstract}

Keywords: academic degrees, Hungarian jurisprudence, CSc, DSc, PhD, habilitation, Hungarian Academy of Sciences.

\section{FROM RATIO EDUCATIONIS TO 1950}

\subsection{University professorship}

Regarding the appointment of university professors and the requirements they are to meet, Article 21 of the 1777 Ratio educationis issued by Maria Theresa reveal the following. Becoming a university professor is conditional upon having 
documented scientific activity. The council of the university can put three nominees forward for the given department through the Governor's Council to the ruler; this wording makes it clear that (using later terminology) it applies to public ordinary university professors. The nominees were invited from academies and grammar schools on the basis of their scientific activity or could be men "living anywhere and known of their excellent erudition". The nominees' curriculum vitae and description of their scientific activity and personality, character were attached to the recommendation, and the ruler selecting from them appointed the given person university professor. The fact that the decree speaks about "providing university lectures" makes it clear that in those days - as we shall see, up to the second half of the $19^{\text {th }} \mathrm{c}$. - only so-called ordinary university professors were allowed to teach at the university. ${ }^{1}$ Consequently, public ordinary university professors obtained their chair through application, their order of priority at the faculty was determined by the date of their appointment, and by public extraordinary university professors they meant professors who did not have their own independent department, in other words, in rank they were placed by all means behind ordinary university professors. ${ }^{2}$

Among the criteria of selecting the above-mentioned nominees for professor Article 102. § of the Decree underlines the importance of professional knowledge and lecturer's competence, their certification by public opinion and published works and, as a criteria outside science, engaging an irreproachable religious and moral conduct. The decree obligatorily stipulates that - in order to decrease "the risk of error" - the professors of the given faculty have the right to express an opinion on the nominees. The need to prove and document lecturer's and teaching competence is determined also as a requirement by the decree. ${ }^{3}$ The option of open invitation was provided by Article 116. $\S$ of the Ratio educationis; to use a modern term, it made it possible for foreign citizens to be employed as university professors, by referring to the point that it is unlawful to consider that "only natives should arrange for studies without damage to public education". Therefore, the possibility to invite persons to a chair must extend not only to the citizens of Hungary and the hereditary provinces but also to "foreign persons famous for their education and scientific lectures". ${ }^{4}$

${ }^{1}$ Friml, Aladár: Az 1777-iki Ratio educationis [Ratio educationis from 1777], Kath. Középiskolai Tanáregyesület, Budapest, 1913, p. 54-55.

${ }^{2}$ Mezey, Barna: Nagyszombattól Budapestig. Az Eötvös Loránd Tudományegyetem Állam-és Jogtudományi Kara (1667-2002) [From Nagyszombat to Budapest. Faculty of State and Law of Eötvös Loránd University (1667-2002)], in Takács, Péter (ed.): A jogászképzés múltja, jelene és jövöje [Past, Present and Future of Legal Education], ELTE ÁJK, Budapest, 2003, p. 148.

${ }^{3}$ Friml: op. cit. p. 199.

${ }^{4}$ Friml: op. cit. p. 208. 
Act 19 of 1848 on Hungarian University determines the principle with respect to university professors that students can freely elect "what subject from what professor they intend to study" and that other "excellent individuals" could teach at the university in addition to ordinary university professors. ${ }^{5}$ On the one hand, the Act subordinated the university to the authority of the Minister of Public Education, ${ }^{6}$ thereby creating and statutorily guaranteeing the autonomy of the university. On the other hand, during the Revolution and War of Independence no further reforms affecting universities and scientific sphere in a wider sense were adopted: the university organisational regulation based on academic freedom was enacted by the Imperial and Royal Ministerial Decree No. 6798 of 1849, which can be linked with the name of Leo von Thun-Hohenstein Minister of Religion and Public Education.?

\subsection{University private professorship}

It was the quoted 1848 Act that introduced the institution of private professors - or, using the term applied in the Act: "other excellent individuals" - in addition to ordinary and extraordinary university professors, which existed up to 1952. In ranking university private professors were placed between professional university professors and the university support staff. ${ }^{8}$ University private professors were not full-time employees of the university; in other words, they were not paid salaries but shared the tuition fee according to the classes held by them. ${ }^{9}$ They obtained their private professor's qualification through habilitation, which vested them - on the grounds of the decision of the public ordinary and extraordinary university professors of the given faculty - with the right to teach the given subject, venia legendi. This qualification procedure was regulated, after numerous former proposals and legal sources - such as, for example, the 1848 draft university regulations made by Baron József Eötvös, the private professors' regulations no. 412 issued by the Studien Hof-Commission of Vienna on 19 December 1848, promulgated at the university of Pest in 1853 and entered into effect in 1858 and the Bill of 1870 made also by Eötvös "On the Repeated Organisation of the Royal Hungarian University of Pest"'l0 - by the private professors' qualification regulation

${ }^{5}$ Section 2 of Act 19 of 1848.

${ }^{6}$ Section 1 of Act 19 of 1848.

${ }^{7}$ Bíró, Judit: Magántanárok a pesti tudományegyetemen 1848-1952 [Private Professor at the University of Pest from 1848 to 1952], ELTE, Budapest, 1990, p. 7.

${ }^{8}$ Bíró: op. cit. p. 12.

${ }^{9}$ Mezey: op. cit. p. 148.

${ }^{10}$ Eötvös, Károly: A pesti királyi magyar egyetem újbóli szervezése tárgyában [On the Repeated Organisation of the Royal Hungarian University of Pest], in: Képviselöházi Irományok, IV., Pest, 1869-1871, p. 262-268. 
of 1871 made by Tivadar Pauler ${ }^{11}$ and then by the Ministerial Decree No. 45. 520/1892 of the Hungarian Royal Minister of Religion and Public Education made by Count Albin Csáky. ${ }^{12}$

It is worth noting why the term private professor became generally accepted in Hungarian university terminology. The phrase is the translation of the German Privatdozent, which remained unchanged during the more than one hundred years of the existence of the institution, however, it drew fierce criticism and numerous unsuccessful attempts at modifications. Due to failure of the motions for modification, the term 'docens' lassociate professor/ was generally used in common talk only, and in 1923 a decree officially prohibited the use of the term; ${ }^{13}$ accordingly, the professor's title was not "enacted" either. ${ }^{14}$

Private professor's habilitation could be carried out the earliest three years after obtaining doctorate, ${ }^{15}$ and the procedure could be commenced if the body consisting of ordinary and extraordinary professors deemed the applicant eligible by secret ballot on the basis of his "personal qualification". ${ }^{16}$ The latter criterion, i.e., personal qualification, allowed several extra-scientific - religious, origin related, political, etc. - aspects to play a part in commencing the habilitation procedure, which might have been all the more injurious since no legal remedy lay against the result of the secret ballot on this subject, requiring simple majority of the votes cast (but dismissing the applicant in case of equality of votes).$^{17}$ In the further phases of the procedure, the applicant's "independent, strictly scientific" habilitation paper "published in printing"18 was reviewed by two experts, within six months' deadline set by the regulations. ${ }^{19}$ If the two opinions were unanimously positive - in case of difference of opinion a third evaluator was appointed ${ }^{20}$ - the faculty council decided whether the applicant could be admitted to oral exam ${ }^{21}$ and trial lecture ${ }^{22}$. When these were successfully performed, the applicant was appointed private professor by the Minister of Religion and Public Education - contrary to public ordinary and extraordinary professors who were

${ }^{11}$ Pauler, Tivadar: Magántanári képesitő szabályzat [Regulation of the Qualification of Private Professors], Budapesti Közlöny 1871/6, p. 157-158.

12 Bíró: op. cit. p. 14.

${ }^{13}$ Ministerial Decree No. 77.893/1923.

${ }^{14}$ Bíró: op. cit. p. 16.

${ }^{15}$ Section 6 of Ministerial Decree No. 45. 520/1892.

${ }^{16}$ Section 8 of Ministerial Decree No. 45. 520/1892.

${ }^{17}$ Bíró: op. cit. p. 22.

${ }^{18}$ Section 4 of Ministerial Decree No. 45. 520/1892.

${ }^{19}$ Sections 8-10 of Ministerial Decree No. 45. 520/1892.

${ }^{20}$ Section 11 of Ministerial Decree No. 45. 520/1892.

${ }^{21}$ Section 13 of Ministerial Decree No. 45. 520/1892.

${ }^{22}$ Sections 14-16 of Ministerial Decree No. 45. 520/1892. 
installed into their office by the king, later on by the governor or the president of the republic. ${ }^{23}$ After that, private professors were granted the decretum habilitationis signed by the rector. ${ }^{24}$ If the applicant was refused in any short listing except for a resolution to dismiss adopted with regard to "personal qualification" - he could lodge an appeal to the Minister ${ }^{25}$ however, if this failed to bring any result, he could try again to obtain private professor's title the earliest two years later. ${ }^{26}$

Some of private professors could become titular public extraordinary university professors pursuant to Decree No. 20.162/1891 of the Minister of Religion and Public Education. The difference between holders of this title - granted by the university on the basis of literary works, but almost entirely not being under the control of the ministry - and private professors was merely that the former could use their title outside the university as well, while they belonged to the same category as private professors within the university system. ${ }^{27}$ The title of titular public extraordinary professor was granted in the following process: two experts expressed an opinion on the documentation analysing the scientific activity of the nominee having worked as a private professor for at least three years, on the basis thereof a body consisting of three persons set up by the faculty made a proposal, which formed the basis of the decision to be usually approved by the Minister of Religion and Public Education. ${ }^{28}$ It should be noted that this rise in title did not make the holder expectant of becoming a public ordinary or extraordinary university professor ${ }^{29}$ therefore, persons belonging to this category were placed between private professors and ordinary or extraordinary university professors in the "order of protocol". 30

The title of titular ordinary university professor introduced in 1910 could be given (i) to retired public ordinary university professors and (ii) to private professors vested with public extraordinary title who had outstanding academic achievement. ${ }^{31}$ This category did not mean any extra right compared to titular extraordinary university professorship, in other words, its introduction served only a kind of seeming rise in title. ${ }^{32}$

\footnotetext{
${ }^{23}$ Bíró: op. cit. p. 34.

${ }^{24}$ Section 18 of Ministerial Decree No. 45. 520/1892.

${ }^{25}$ Section 19 of Ministerial Decree No. 45. 520/1892.

${ }^{26}$ Section 21 of Ministerial Decree No. 45. 520/1892.

${ }^{27}$ Bíró: op. cit. p. 48.

${ }^{28}$ Ministerial Decree No. 11.041/1868.

${ }^{29}$ Ministerial Decree No. 24/114/1876.

${ }^{30}$ Bíró: op. cit. p. 49.

${ }^{31}$ Ministerial Decree No. 85.107/1910.

${ }^{32}$ Bíró: op. cit. p. 50.
} 


\section{THE SYSTEM OF ACADEMIC DEGREES INTRODUCED FOLLOWING THE SOVIET PATTERN}

By 1952 the former scientific qualification system was definitively terminated pursuant to the provisions of Law-decrees 44 of 1950 and 26 of 1951 and was replaced by the centralised pattern adopted from the Soviet Union, where it was introduced in $1934^{33}$, which contained the candidate of sciences and doctor of sciences degrees conferred by the HAS and the university doctor title and later degree conferred by universities.

\subsection{The candidate's degree}

The candidate of sciences (Candidatus Scientiarum, C.Sc.) degree was introduced by Law-decree 44 of 1950 on "the introduction of a new academic degree and regulations of obtaining it" promulgated on 26 November 1950 - as the Preamble of the Law-decree puts it - "... in order to ensure planned scientific and professional recruitment, following the example of the Soviet Union's leading scientific cadre training program...". ${ }^{34}$

The Law-decree entrusted the Hungarian Academy of Sciences with controlling the training that served the basis of the candidate's degree, which exercised this duty through the National Scientific Qualification Committee, from 1951 through the Scientific Classification Committee ${ }^{35}$ replacing the former ${ }^{36}$. Obtaining the degree was conditional upon aspirantship, i.e., candidate training, a dissertation proving capability of independent scientific research and defending it before the committee designated by the National Scientific Qualification Committee. ${ }^{37}$ The maximum duration of aspirantship was three years as stipulated by law, however, in certain cases this duration was determined by the National Scientific Qualification Committee, taking account of the character of the branch of science and the preparedness of the aspirant. ${ }^{38}$ For the period of training, i.e., aspirantship, the nominee had to be assigned to the scientific institute determined by the National Scientific Qualification Committee ${ }^{39}$ and his professional activity was controlled by the aspirant supervisor. ${ }^{40}$ During the period of candidate training the aspirant obtained a state scholarship and the aspirant supervisor was paid

\footnotetext{
${ }_{33}^{3}$ Волков, М. Н.: Кандидат наук, in: Большая советская энщиклопедия ХХ., Государствзнное Научное Издательство, Москва, 1953, p. 3.

${ }^{34}$ Preamble of Law-decree 44 of 1950.

${ }^{35}$ Section 4 of Law-decree 26 of 1951.

${ }^{36}$ Section 1 (1) of Law-decree 44 of 1950.

${ }^{37}$ Section 2 (1) of Law-decree 44 of 1950.

${ }^{38}$ Section 3 (1) of Law-decree 44 of 1950.

${ }^{39}$ Section 5 (1) of Law-decree 44 of 1950.

${ }^{40}$ Section 5 (2) of Law-decree 44 of 1950.
} 
a fee depending on the number of aspirants controlled by him ${ }^{41}$ to the debit of the budget of the HAS. ${ }^{42}$ The latest until the end of the first academic year, the aspirant took a preliminary examination in the subjects of the candidate's exam before the designated board of examiners ${ }^{43}$ and at the end of the training period he took the candidate's exam, where he gave account of his professional and ideological (as the law puts it "Marxist-Leninist") expertise and foreign language skills. ${ }^{44}$ It was possible to obtain the candidate's degree also without completing the aspirant training, on condition that the nominee had taken his candidate's exam, made his dissertation and defended it with the special authorisation of the National Scientific Qualification Committee, ${ }^{45}$ in other words, "individual preparation" was an option in case of the candidate's degree as well. The candidate's degree could be obtained also when it was conferred by the National Scientific Qualification Committee "on the basis of formerly achieved scientific merits serving the benefit of the people" without taking any aspirant's exam, writing any dissertation or defending it ${ }^{46}$ - this solution was used in several cases regarding scientists who were appointed university professors earlier.

With respect to the persons holding a candidate's degree in all branches of science, it is worth mentioning three records: while in 19612266 persons holding a candidate's degree were registered, this number rose to 9885 in 1990; in the period of the existence of the candidate's degree a total of 17434 candidate's certificates were issued ${ }^{47}$ For the last time applications for obtaining a candidate's degree could be submitted in 1997, the matters in progress were concluded in the following one or two years. Contrary to $\mathrm{PhD}$, as we shall see, it was usually rare for a scientist to obtain the candidate's degree under the age of forty. ${ }^{48}$

\subsection{The doctor of sciences degree}

In the year following the introduction of the candidate's degree Law-decree 26 of 1951 on the introduction of the academic degree doctor of sciences and regulation of university lecturer's and research institute positions and degrees arranged for setting up the degree doctor of sciences (Doctor Scientiarum, D.Sc.). The Preamble of the Law-decree referred to the earlier Law-decree 44 of 1950 and

${ }^{41}$ Section 6 (1) of Law-decree 44 of 1950.

42 Section 6 (2) of Law-decree 44 of 1950.

${ }^{43}$ Section 7 of Law-decree 44 of 1950.

${ }^{44}$ Section 8 (1) of Law-decree 44 of 1950.

${ }^{45}$ Section 9 (1) of Law-decree 44 of 1950.

${ }^{46}$ Section 9 (2) of Law-decree 44 of 1950.

${ }^{47}$ Nagy, Péter Tibor: A tudományos továbbképzés Kádár-korszakbeli társadalomtörténetéhez [Postgraduate Education in the Kádár-Era], Kultúra és közösség 2011/2., p. 26.

${ }^{48}$ Pálinkó, Éva: Fiatal kutatók életútja és szakmai identitása [Course of Life and Professional Identity of Young Researchers], PhD-Thesis, BCE, Budapest, 2009, p. 22. 
pointed out that "on the basis of the experience of the Soviet Union it is necessary to introduce [...] the academic degree doctor of sciences" as the former (old system doctoral and private professor's) "degrees do not sufficiently help enhancement of the general standard of our scientific life" and "do not sufficiently urge our researchers to carry out increased scientific work and to widen their knowledge". 49 The Preamble of the legal rule also underlined that it is necessary to regulate the system of university lecturer's and research institute positions as well, noting that for the time being filling these positions is not conditional upon holding either the candidate of sciences or the doctor of sciences degree, however, for the future "persons who fill the highest positions are expected to be possibly candidates or doctors as soon and in as many number as possible". 50

The doctor of sciences degree - i.e., emphatically not a title but the highest grade of the scientific qualification system - "is the sign of acknowledgement of high-level scientific achievement", ${ }^{51}$ which can be won by those who have already obtained the candidate of sciences degree, have in-depth and overall knowledge in the given field of their branch of science, have showed new results based on their independent researches and defended their doctor's thesis". ${ }^{52}$ The Law-decree made it possible to win the doctor of sciences degree exceptionally without holding a candidate's degree and writing a dissertation for those who deserved it by their scientific achievements of especially great significance. ${ }^{53}$ According to this regulation, the ordinary and corresponding members of the HAS were entitled to the doctor of sciences degree, ${ }^{54}$ which was obviously aimed at conferring a degree upon scientists who were elected academicians earlier before introduction of the new type of degrees. The legal rule ordered that both candidates and doctors of sciences should use the specification of their branch of science with their name ${ }^{55}$ and should be provided with emolument supplement. ${ }^{56}$ With respect to conferring both the candidate's and the doctor of sciences degree - in order to replace the National Scientific Qualification Committee set up earlier regarding the candidate's degree - the above cited Law-decree ordered to set up the Scientific Classification Committee within the HAS, whose members were to be appointed upon the proposal of the HAS by the Council of Ministers. ${ }^{57}$

With regard to winning the doctor of sciences degree, the Law-decree set the following order of procedure. Applications for obtaining the degree could be

${ }^{49}$ Preamble of Law-decree 26 of 1951.

${ }^{50}$ Preamble of Law-decree 26 of 1951.

${ }^{51}$ Section 1 (1) of Law-decree 26 of 1951.

${ }^{52}$ Section 1 (2) of Law-decree 26 of 1951.

${ }^{53}$ Section 1 (3) of Law-decree 26 of 1951.

${ }^{54}$ Section 2 of Law-decree 26 of 1951.

${ }^{55}$ Section 3 (1) of Law-decree 26 of 1951.

${ }^{56}$ Section 3 (2) of Law-decree 26 of 1951.

${ }^{57}$ Section 4 of Law-decree 26 of 1951. 
submitted the earliest three years after winning the candidate's degree - the Scientific Classification Committee could exempt applicants from compliance with this period exceptionally $-{ }^{58}$ the application had to be lodged with the dean of the given university faculty addressed to the Scientific Classification Committee. ${ }^{59}$ The applicant marked one of his dissertations and monographs as doctor's thesis and attached it to his application - as an exception the legal rule made it possible for nominees presenting exceptional scientific achievement who had only one dissertation to win the doctor of sciences degree. ${ }^{60}$ The submitted dissertation was delivered by the dean of the university faculty to the scientists of the given field for review and the so developed opinion was submitted by him to the Scientific Classification Committee.$^{61}$ In view of the fact that the candidate's dissertation and the application for winning the degree had to be forwarded to the Scientific Classification Committee through the dean of the faculty and that the preliminary opinion expressed on the dissertation was made by two experts designated by the dean, it was unavoidable that the evaluation should be influenced by ideological, political and personal criteria outside academic considerations as well. ${ }^{62}$

The Scientific Classification Committee designated three evaluators to review the dissertation and when the opinion of two of them was favourable, the dissertation was put to public debate before the designated special committee of the Academy. ${ }^{63}$ On the basis of the judgements, the debate and the special committee's proposal, the Scientific Classification Committee adopted decision on conferring the doctor of sciences degree by secret ballot; in case of favourable decision, the certificate was issued, which was delivered by the council of the university the application was submitted to.$^{64}$ The regulations do not contain any reference to whether the decision of the Scientific Classification Committee had to be adopted by a simple or qualified majority of the votes cast, which allows to presume that conferring the degree was decided by simple majority.

With respect to formerly issued titles, the Law-decree made the following decision. The holders of these titles could submit an application based on which the Scientific Classification Committee examined until 30 September 1952 whether they could get the doctor of sciences or candidate of sciences degree. ${ }^{65}$ In this interim period the Scientific Classification Committee (i) could confer any of the new degrees upon the applicant without submitting any dissertation or (ii) could

\footnotetext{
58 Section 5 (1) of Law-decree 26 of 1951.

${ }^{59}$ Section 5 (2) of Law-decree 26 of 1951.

${ }^{60}$ Section 5 (3) of Law-decree 26 of 1951.

${ }^{61}$ Section 6 (1) of Law-decree 26 of 1951.

62 Nagy: op. cit. p. 23.

${ }^{63}$ Section 6 (2) of Law-decree 26 of 1951.

${ }^{64}$ Section 6 (2) of Law-decree 26 of 1951.

${ }^{65}$ Section 7 (1) of Law-decree 26 of 1951.
} 
dismiss the application or (iii) could set the conditions that the applicant had to satisfy in order to win the appropriate degree. ${ }^{66}$ By entering into effect, the Law-decree cancelled the option of conferring the doctoral title (dr. jur.) as part of granting the diploma - similarly, as from 1 January 1952 it terminated issuance of doctoral titles in such a form at medical universities - instead of it, it ordered to use the specification 'qualified' (qualified jurist) ${ }^{67}$ however, it made it possible for "old system doctors" to continue to use this title. ${ }^{68}$ (This regulation was in effect only for a short period; from 1953 lawyers and physicians were given doctoral title again together with their diploma.)

\section{THE SYSTEM OF ACADEMIC DEGREES AND TITLES AFTER THE CHANGE OF REGIME}

The need for transforming the scientific qualification system developed in $1950 / 51$, primarily the necessity to return the right to confer the doctoral degree to universities became apparent shortly after the change of regime. This was made emphatically necessary by two circumstances: on the one hand, the Conference of European Universities (CRE) admitted as its members only universities that - in accordance with ancient university privileges - had the right to confer doctoral degrees; on the other hand, the candidate of sciences degree did not appear to be compatible in the international scene; it was a subject of dispute, for example, whether, taking the West German system as basis, the candidate's degree could be considered equal to promotion or habilitation. ${ }^{69}$

Below we shall discuss the doctoral, i.e., PhD degree, now the only degree in Hungary's scientific life, habilitation that represents a prerequisite for taking certain positions in the scientific qualification system (associate professor, university professor, senior research fellow, research advisor) and the doctor of the HAS title replacing D.Sc. After that we shall dwell on the rules of becoming a member of the Academy.

\subsection{The doctoral degree $(\mathrm{PhD})$}

As a result of the above outlined attempt, by Act LXXX of 1993 on Higher Education the currently effective scientific qualification system was developed that now defines only a single uniform academic degree, $\mathrm{PhD}$ and under which

\footnotetext{
${ }^{66}$ Section 7 (2) of Law-decree 26 of 1951.

${ }^{67}$ Section 8 (1) of Law-decree 26 of 1951.

${ }^{68}$ Section 8 (3) of Law-decree 26 of 1951.

${ }^{69}$ Róna-Tas, András: A magyar doktori iskolák helyzete és jövöje [Status and Future of Postgradual Schools in Hungary], Magyar Tudomány 2003, p. 1298.
} 
the doctor of the HAS title replacing the doctor of sciences degree is now considered a title rather than a degree. (It should be noted that the titles $d r$. jur. of jurists and $d r$. med. of physicians - just as the titles $d r$. med. dent. of dentists, $d r$. pharm. of pharmacists and $d r$. vet. of veterinarians - are not academic degrees but titles, part of their diploma. ${ }^{70}$ ) $\mathrm{PhD}$ is nothing else then the abbreviation of the Latin philosophiae doctor. The official abbreviations of the term in Anglo-Saxon countries is also $\mathrm{PhD}$ - sometimes Dphil; in German language areas dr. phil. (Promotion, Doktor der Wissenschaften); the equivalent of $\mathrm{PhD}$ in the science of the arts is DLA (Doctor of Liberal Arts, Doctor Liberalium Artium). ${ }^{71}$

Act LXXX of 1993 on Higher Education already refers to the PhD degree and habilitation and mentions the relation of the candidate's degree to $\mathrm{PhD}$. As a condition of founding and operating universities the Act, among others, defines doctoral training and suitability for conferring the doctoral $(\mathrm{PhD})$ and master's (DLA) degree and conducting the habilitation procedure as a required condition. ${ }^{72}$ Regarding the doctoral degree, in 1993 the Act formulated as follows: "Whenever this Act refers to doctoral degree as requirement for employment, engagement, qualification or other legal rule refers to academic degree as requirement for employment, engagement, qualification, then it shall be interpreted as the doctoral degree as set out in this Act, the candidate of sciences, doctor of sciences degree or an academic degree obtained abroad and registered or acknowledged inland. As from entry into force of this Act, the persons who hold the candidate of sciences degree can use the specification 'doctoral degree'." 73 The latter sentence makes it clear that candidate's degrees were automatically re-qualified as PhD. In spite of this formal identity, András Róna-Tas declared with regard to degrees that $\mathrm{PhD}$, i.e., the doctoral degree conferred by the university"...did not replace the candidate's degree but indicated transfer to a new system simultaneously with termination of the latter." 74

Act CCIV of 2011 on National Higher Education formulates the following with regard to the doctoral degree. After obtaining the master's degree - regarding jurists, as appropriate, in view of undivided lawyer's training, after obtaining the diploma - doctoral training prepares $\mathrm{PhD}$ students for the doctoral degree. The Act declares that the university obtains the right to perform doctoral training and confer doctoral degree in the field of science - more specifically within the branch of science - to which its operation licence extends; the doctor's certificate is signed by the rector and the chairman of the council of doctors. Furthermore, the Act determines that it is the right of the council of doctors of the university to organise

\footnotetext{
${ }^{70}$ Section 52 (7) of Act CCIV of 2011.

${ }^{71}$ Section 87/F (4) of Act LXXX of 1993 and Section 16 (4) of Act CCIV of 2011.

72 Section 3 (1) of Act LXXX of 1993.

${ }^{73}$ Section 119 (1)-(2) of Act LXXX of 1993.

${ }^{74}$ Róna-Tas: op. cit. p. 1298.
} 
the doctoral training and confer the doctoral degree and that the council of doctors of the university can set up a council of doctors for each field of science and that each member of the council of doctors, except for would-be doctor representatives, must have an academic degree. ${ }^{75}$

Furthermore, the Act defines doctoral training, which can be individual or group training, research and reporting activity in line with its peculiarities and the would-be doctor's needs. After the doctoral training, the procedure of obtaining doctoral degree begins; the name of the former $\mathrm{PhD}$ student applying for degree is: candidate for doctor; the legal relation of the candidate for doctor is established through application for the procedure of obtaining a degree and its acceptance - the university cannot dismiss the application of those who have successfully completed the doctoral training at the given university. However, it is possible to obtain doctoral degree, subject to satisfying certain conditions, even without participating in the doctoral training preceding it as a so-called individual preparer. The legal relation of the candidate for doctor can terminate, as appropriate, by conclusion of the procedure of obtaining a degree and in the event that the candidate for doctor failed to submit his doctor's thesis within two years from establishing the legal relation. The Act determines the conditions of obtaining a degree in highly great details as follows: in addition to fulfilling the requirements set out in the doctoral regulations, completing the doctoral examination before (at least) a three-member board of examiners; certifying knowledge of two foreign languages at a level defined in the doctoral regulations; documenting independent scientific activity by articles and studies (or "otherwise", which is difficult to interpret within the frameworks of obtaining a degree in jurisprudence); presenting the dissertation and defending it in a public debate. ${ }^{76}$ According to the interpretation of the Act, the dissertation "is a piece of writing, creation or work made by the candidate for doctor, by which the candidate for doctor proves during the procedure of obtaining doctoral degree that he is able to solve scientific tasks set in accordance with the requirements of the decree independently". ${ }^{77}$ The Act requires maintenance of a central register of doctoral degrees accessible for anybody and that it should be made public electronically ${ }^{78}$ - this is served currently by the web site www.doktori.hu. As appropriate the Act entrusts the doctoral regulations of the given university with regulating several issues. ${ }^{79}$ Pursuant to the Act, holders of $\mathrm{PhD}$ degree can use the abbreviation $\mathrm{PhD}$ or Dr. with their names. ${ }^{80}$

\footnotetext{
${ }^{75}$ Section 16 (1)-(5) of Act CCIV of 2011.

${ }^{76}$ Section 53 (1)-(5) of Act CCIV of 2011.

${ }^{77}$ Section 108 (1) of Act CCIV of 2011.

${ }^{78}$ Section 53 (6) of Act CCIV of 2011.

${ }^{79}$ Section 53 (6) of Act CCIV of 2011.

${ }^{80}$ Section 53 (7) of Act CCIV of 2011.
} 
The Act regulates publicity of doctor's dissertations and the theses of doctor's dissertations as well. It is the university that shall arrange for registering them electronically and in printed form and making them public in their full volume; in other words, for placing a printed copy and a copy recorded on electronic data carrier of the dissertations and the theses at the central library of the university. Also, publicity is to be ensured by the provision that requires that the doctor's dissertation and its theses in electronic form shall be made accessible to anybody in the Database of Hungarian Scientific Publications (MTMT) ${ }^{81}$ with a DOI identity code attached to them..$^{82}$

Government Decree No. 387/2012. (XII. 19.) on Doctoral Schools, the Order of Doctoral Procedures and Habilitation sets forth, among others, the following with regard to the procedure of obtaining a degree. The board of examiners for the doctoral examination (whose chairman can be only a university professor, professor emeritus or habilitated professor) must consist of at least three members, where one of them - if the number of the board members does not amount to five persons - shall not maintain any legal relation aimed at employment with the given university. ${ }^{83}$ Regarding the thesis booklet the Decree determines that it shall present the results of independent scientific activity in a summary form. ${ }^{84}$ The doctor's dissertation shall be submitted simultaneously with submitting the application for commencing the procedure of obtaining a degree or within two years from accepting the application. ${ }^{85} \mathrm{With}$ regard to deadlines, the Decree sets forth that the procedure of obtaining a degree shall be concluded within one year from submitting the dissertation, ${ }^{86}$ and as an incompatibility rule it declares that next of kin of the person concerned and any person who cannot be expected to judge the matter objectively shall not act as evaluator or a board member in the procedure. ${ }^{87}$

\subsection{Habilitation}

According to the definition of the effective Higher Education Act, habilitation "is judging academic's and lecturer's competence and scientific achievement by the institution". ${ }^{88}$ The term itself comes from the Latin word habilis, meaning suitable and accordingly in time it denoted suitability for independently announcing, registering main courses of lectures, university subjects. However, this meaning

\footnotetext{
${ }^{81}$ www.mtmt.hu

${ }^{82}$ Section 53/A (1)-(2) of Act CCIV of 2011.

${ }^{83}$ Section 12 (3) of Government Decree No. 387/2012.

${ }^{84}$ Section 14 (1) of Government Decree No. 387/2012.

${ }^{85}$ Section 14 (2) of Government Decree No. 387/2012.

${ }^{86}$ Section 16 (9) of Government Decree No. 387/2012.

${ }^{87}$ Section 17 of Government Decree No. 387/2012.

${ }^{88}$ Section 108 (7) of Act CCIV of 2011.
} 
developed as the result of a longer process. It was at the end of the $18^{\text {th }}$ century, in the world of German universities that they formulated the need for the first time that lecturers should prove their academic and lecturer's competence as Privatdozent at the university. At regulations level, the requirement of habilitation was recorded for the first time at the Reformuniversität of Berlin founded in 1810 in the statute adopted in 1812 and entered into effect in 1816 - at the same time, it should be noted that in those days habilitation was not to mean some kind of second doctoral degree (Promotion) and did not contain any habilitation paper (Habilitationsschrift) as requirement for creating some kind of great summary work. ${ }^{89}$ No uniform regulation was developed on this matter in the $19^{\text {th }}$ century, however, customary law set that usually two years must pass between promotion, i.e., doctoral degree and habilitation, although this depended on the age and university and was highly changing. The requirement of writing a habilitation paper, which definitely exceeded the doctor's dissertation in terms of both its volume and standard, became a general requirement at the beginning of the $20^{\text {th }}$ century. ${ }^{90}$

As we have seen, habilitation was defined in the Hungarian university system before the changes that occurred in 1950/51 since it was a prerequisite for private professor's qualification. The two analysed law-decrees (Law-decree 44 of 1950 and Law-decree 26 of 1951) terminated habilitation as a scientific qualification procedure since conducting them and conferring the degree fell within the powers of universities and as such did not fit in with the centralised system of academic degrees developed following the Soviet pattern.

Habilitation was brought back into the Hungarian university system by Act LXXX of 1993, which set the following provisions in this respect. The prerequisite for habilitation is that the applicant should have a doctor's degree and should prove his scientific, professional results and the achievements attained by him as lecturer, research fellow in practical and creative activities after obtaining the doctor's degree, in the form determined in adherence to the habilitation regulations of the university. The applicant had to give account of his lecturer's competence in public, free lectures in Hungarian and a foreign language..$^{91}$ Development of the detailed rules of the habilitation procedure was assigned by the Act to the powers of universities. ${ }^{92}$ Furthermore, the Act stipulated that university professors appointed before the Act entered into effect shall be considered habilitated $;{ }^{93}$ in

\footnotetext{
${ }^{89}$ vom Bruch, Rüdiger: Qualifikation und Spezialisierung. Zur Geschichte der Habilitation, Forschung und Lehre 2000, p. 69.

${ }^{90}$ Schubert, Ernst: Die Geschichte der Habilitation, in: Koessler, Henning (Hrsg.): 250 Jahre Friedrich-Alexander-Universität Erlangen Nürnberg, Universtätsbund Erlangen, Erlangen, 1993, p. 125., 134., 151.

${ }^{91}$ Section 25 (1)-(4) of Act LXXX of 1993.

${ }^{92}$ Section 26 (5) of Act LXXX of 1993.

${ }^{93}$ Section 123 (1) of Act LXXX of 1993.
} 
other words, it did not instruct universities to conduct the habilitation procedure with regard to university professors holding the doctor of sciences degree or, in certain cases, the candidate of sciences degree since university professors were appointed on the basis of the candidate's degree as well.

The effective law, i.e., Act CCIV of 2011 on National Higher Education assigns regulation of the rules of habilitation to the level of Government Decree, ${ }^{94}$ which authorisation was performed - just as in the case of the doctoral procedure - also by Government Decree No. 387/2012. (XII. 19.) on Doctoral Schools, the Order of Doctoral Procedures and Habilitation. Pursuant to it - considering only provisions applying to jurisprudence and omitting provisions regarding technical and arts activities - commencement of the habilitation procedure can be applied for when the nominee has pursued high level, independent scientific activity since obtaining his doctoral $(\mathrm{PhD}$ ) degree (for at least five years); has delivered lectures at some higher education institution either in Hungary or abroad for at least eight semesters; his scientific works have been published in noted international, authoritative periodicals edited by consultant editors and references to his works were made in such periodicals (as certified by the MTMT database); and has regularly attended international and inland scientific conferences as a lecturer ${ }^{95}$ The nominee sums up the results of his scientific activities performed since obtaining the doctor's degree in theses; yet, the habilitation committee or regulations of the given university can require submission of a habilitation dissertation as well. ${ }^{96}$

As part of the habilitation procedure, a so-called habitus investigation is carried out to establish how the nominee has satisfied the set conditions; this is followed by the evaluation of the habilitation theses. If both evaluations are positive, the nominee will hold a habilitation lecture in Hungarian and a foreign language, which is followed by public debate. ${ }^{97}$ The theses and the dissertation as well as the lecture and the public debate are evaluated by the jury - with respect to its composition the criteria determined in the procedure of obtaining doctor's degree shall be applied appropriately. ${ }^{98}$ As the closing act of the procedure - in the case that the lecture and the public debate is evaluated positively - on the basis of the report of the jury, the habilitation committee of the university confers the habilitated doctor's degree upon the nominee and issues a habilitation certificate thereon (decretum habilitationis), ${ }^{99}$ which entitles its holder to bear the title habilitated doctor (in abbreviated form: dr. habil.). ${ }^{100}$

\footnotetext{
${ }^{94}$ Section 110 (25) of Act CCIV of 2011.

${ }^{95}$ Section 21 (2) of Government Decree No. 387/2012.

${ }^{96}$ Section 21 (3) of Government Decree No. 387/2012.

${ }^{97}$ Section 22 (5) of Government Decree No. 387/2012.

98 Section 23 (3) of Government Decree No. 387/2012.

${ }^{99}$ Section 24 (1) of Government Decree No. 387/2012.

${ }^{100}$ Section 21 (1) of Government Decree No. 387/2012.
} 


\subsection{The doctor of the HAS (MTA) title}

As we have referred to it already, in 1994 Act XL of 1994 on the Hungarian Academy of Sciences "changed" the doctor of sciences (D.Sc.) degree introduced in 1951 into the doctor of the HAS title, thereby the degree became a title - a title not lower at all in prestige, although not precisely defined in the system of scientific qualification and professional progress. At present the HAS has 55 doctors (except for the ordinary and corresponding members of the Academy) in legal and political sciences, including those who had obtained the doctor of sciences degree earlier.

The Act sets forth that the doctor of the HAS degree can be conferred by the Council of Doctors of the Academy upon persons "who have attained outstanding scientific achievements" - which is, as a matter of fact, conditional upon holding an academic degree and complying with other conditions of obtaining the degree set by the doctoral regulations of the Academy. ${ }^{101}$ The Act reasonably declares that the formerly obtained doctor of sciences degree is equal to the doctor of the HAS title. ${ }^{102}$ Also, the Act on the HAS sets forth that the doctors of the HAS who live in Hungary can be provided with monthly honorarium by the Academy until the end of their life and that the annual amount of the honorarium of all the doctors of the HAS cannot exceed 1.8 times the annual honorarium of all the academicians. ${ }^{103}$

Pursuant to the Statutes of the Hungarian Academy of Sciences the doctor of the HAS title can be conferred upon persons holding an academic degree who have enriched their science subject with original results after obtaining the degree, pursue outstanding scientific activity known to and acknowledged by the authoritative inland and international circles of the relevant field and sum up their findings in a doctor's dissertation. ${ }^{104}$ The Statutes empowered the Council of Doctors of the Academy to work out the Doctoral Regulations of the HAS and the Rules of Procedure of the Council of Doctors, which can stipulate further requirements in addition to the above. ${ }^{105}$ The special procedural and requirement system of Section IX of the Academy, i.e., Section of Economics and Law, applicable to doctoral matters entered into effect in September 2013. ${ }^{106}$

The rules of procedure of Section IX and the special requirements set by the Committee on Legal and Political Sciences distinguish three forms of the doctor's dissertation: a dissertation made in order to obtain the title, based on scientific results attained after obtaining the previous degree, in the volume of minimum 12 , maximum 16 author's sheets without appendices and bibliography; a mono-

\footnotetext{
${ }^{101}$ Section 8 (1) of Act XL of 1994.

102 Section 8 (5) of Act XL of 1994.

103 Section 8 (3) of Act XL of 1994.

104 Section 24 (1) of Statutes of the Hungarian Academy of Sciences http://mta.hu/cikkek/ akademiai-szabalyozasok-119791

${ }^{105}$ Section 24 (2)-(3) of Statutes of the Hungarian Academy of Sciences

$106 \mathrm{http} / / / \mathrm{mta} . \mathrm{hu} / \mathrm{ix}$ _osztaly_cikkei/doktori-ugyek-121451
} 
graph published maximum three years earlier, based mostly on the results attained in the period after obtaining the previous degree; and a so-called short dissertation, in which the applicant sums up his independent scientific theorems. ${ }^{107}$ Summary theses must be attached to the doctor's dissertation, which (i) can follow the usual structure of dissertations (objective, method, results, utilisation, bibliography), or (ii) can contain only the main points of thesis, including an introduction and a list of publications certifying originality of the theses. ${ }^{108}$

The Statutes separate seven phases of the doctoral procedure: submission of the application; habitus investigation (i.e., qualification of the applicant's scientific activity, personal suitability, where the scientific committee expresses an opinion on the applicant and in case of positive opinion the scientific section drafts a proposal towards the Council of Doctors, which makes the decision); putting up for judgement and defending procedure, carried out on the basis of the decision of the Council of Doctors; review of the doctor's dissertation by three external examiners; putting to debate by the Council of Doctors on the basis of the proposal of the three adjudicators; public debate (as a result of which, on the basis of the three external examiners' opinion, the jury makes a proposal to the scientific section on conferring the title); and conferring the title on the basis of the proposal of the scientific section by the Council of Doctors. ${ }^{109}$

\subsection{Membership in the Academy}

Act XL of 1994 amended in 2011 provides that the Hungarian Academy of Sciences is made up by (inland) ordinary and corresponding and (foreign) external and honorary members. With regard to being elected an academician, the Act sets forth no more than that academicians are elected by inland members and that the number of inland academicians younger than 70 cannot be more than two hundred, and the total number of inland academicians can be maximum 365 persons; also it stipulates that inland academicians living in Hungary are provided with monthly honorarium. ${ }^{110}$ At present Section IX of the Academy has 30 (25 ordinary and 5 corresponding) members, including 11 (9 ordinary and 2 corresponding) members in the field of legal and political sciences.

By its Resolution No. 5/2012 the HAS's General Assembly regulated the detailed procedural rules of electing academicians. ${ }^{111}$ Academicians are elected

\footnotetext{
${ }^{107}$ Section (1) of Doctoral Regulations of the HAS, Rules of Procedure of the Council of Doctors

${ }^{108}$ Section (3)-(4) of Doctoral Regulations of the HAS, Rules of Procedure of the Council of Doctors

${ }^{109}$ Section 24 (4) of Statutes of the Hungarian Academy of Sciences

${ }^{110}$ Section 6 (1)-(4) of Act XL of 1994.

${ }^{111} \mathrm{http}: / / \mathrm{mta} \cdot \mathrm{hu} / \mathrm{data} / \mathrm{cikk} / 13 / 10 / 17 / \mathrm{cikk}$ _131017/2013_evi_akademikusvalasztas_eljarasi_szabalyzata.pdf
} 
in every three years in May, when members are elected by the Assembly of Academicians. ${ }^{112}$ Recommendations for membership in the Academy can be submitted by members of the Academy to the competent section, evaluating therein the scientific activity of the proposed person, his outstanding scientific results and their acknowledgement at home and abroad. The recommendations examined and forwarded by the Presidium are published in the periodical Hungarian Science. ${ }^{113}$

Being a candidate for membership, no matter whether being nominated as an ordinary, corresponding, external or honorary member, requires at least three recommendations. Minimum three ordinary members' recommendation is required for ordinary membership; minimum three inland members' recommendation is required for corresponding membership; at least three inland or two inland and one external members' recommendation is required for external membership; at least three inland members' recommendation is required for honorary membership. The Resolution regulates the number of recommendations that one member can put forward: each ordinary, corresponding and external member can recommend two persons, ordinary members can make two recommendations in each of the four categories; corresponding and external members can make two recommendations in each of the three categories (reasonably they cannot make recommendations on ordinary members); honorary members cannot make recommendations. ${ }^{114}$

The earliest four weeks after the recommendations are published in the Hungarian Science, the scientific section holds a so-called member nomination section meeting, attended by inland academicians with right to vote - as a matter of fact, external and honorary members have right of consultation only. The member nomination section meeting adopts resolution on the nomination of the proposed persons by secret ballot and simple majority of the votes cast, and those who have won this share of the votes will be put on the common list of nominees for academicians. The result of the voting of the member nomination section meeting ranks the voted nominees as well. The order is determined by the decreasing number of "yes" votes or, in case of identical number of "yes" votes, by the increasing number of "no" votes. The president of the section informs the Presidium on the result of voting, and the Presidium unites the lists of nominees into a common list of nominees where it is bound by the order set by the section. The number of eligible new members and their distribution among sections are determined by the member election meeting of the Assembly of Academicians. ${ }^{115}$

\footnotetext{
${ }^{112}$ Section 2 (1)-(4) of Procedural Rules of Electing Academicians of the HAS

${ }^{113}$ Section 3 (1)-(5) of Procedural Rules of Electing Academicians of the HAS

${ }^{114}$ Section 4 (1)-(3) of Procedural Rules of Electing Academicians of the HAS

115 Section 5 (3)-(7) of Procedural Rules of Electing Academicians of the HAS
} 


\section{SUMMARY}

The prime aim of this study was to survey the system of academic degrees and titles used in Hungary and the related university lecturer and research fellow classing - as appropriate, setting out primarily from the field of legal and political sciences. However, in view of the fact that currently used degrees and titles can be traced back to longer or shorter historical precedents, a historical analysis seemed to be necessary as well. For example, habilitation as a condition of private professor's qualification appeared in Hungarian scientific life as early as in the $19^{\text {th }}$ century, and although the candidate of sciences and doctor of sciences degrees introduced following Soviet patterns are no longer conferred, it is possible to continue to hold them and they have been included in the scientific qualification system.

We set out from the year 1777 when Ratio educationis was issued by Maria Theresa, which marks the starting point of a long period of development up to 1950. It was in this period when the system of qualification and required conditions of ordinary and extraordinary university professorship and, from the second half of the $19^{\text {th }}$ century, of university private professorship evolved. This organic system complying with Western European patterns was ended by two law-decrees issued in 1950 and 1951. This step, on the one hand, terminated the former scientific qualification and classification system and introduced the Soviet type candidate of sciences and doctor of sciences degrees as well as the university classification system that is used up to this day (which defines assistant lecturer's, senior lecturer's, associate professor's and university professor's scopes of work); and, on the other hand, centralised Hungarian scientific life by depriving universities of their powers of scientific qualification.

The bases of effective regulations were created in 1993 when the transformation of the scientific qualification system introduced following Soviet patterns began. It was at that time when the PhD, i.e, doctor's degree was introduced following western examples, which has now become the only conferable academic degree in Hungary - all other qualifications are considered "merely" a title. Regarding the $\mathrm{PhD}$ degree, we have analysed not only statutory provisions and requirements but also the possibilities of institutional regulations. Partly according to former Hungarian traditions, partly following Western European (primarily German) patterns, habilitation as a step of scientific career following $\mathrm{PhD}$ has been reinstated among academic titles. The issuance and conferment of both the $\mathrm{PhD}$ (doctor's) degree and dr. habil. title have been assigned to the powers of universities. The doctor of sciences degree has been replaced by the doctor of the HAS title; as a matter of fact, conferring this title has stayed within the powers of the Hungarian Academy of Sciences, however, the conditions of obtaining it have become stricter. As the highest academic title, membership (primarily corresponding and ordinary membership) in the Academy has been preserved - at present Section IX of the HAS (Section of Economics and Law) enumerates 11 legal scientist members. 
Др Тамащ Нойари, ванредни иррофесор

Универзитетеи „, Sapientia“, Клуж-Найока

Дейаримман за ирраво

tamasnotari@yahoo.de

\section{Историјат академских степена и звања у области правне науке у Мађарској}

Сажеейак: У овом раду ауйор у светилу истиоријског̄ развоја истиражује системем академских сииеиена и значајних академских звања (имајући у виду иравну науку, изостиављајући академска звања ван ове обласиии) корищћених у Мађарској. Прво анализира захиееве и законске услове који су били неойходни да би неко йосӣао универзииетеиски ирооресор (редовни и ванредни универзитетеиски йрофесор) и ириваитни универзииетеиски ирофесор (Privatdozent) у йериоду йочев од Ratio educationis Mapије Терезије из 1777. г̄одине, све до 1950. гоодине. После тиога а излаже увођење и регуулисање академских сииейена уведених 1950. и 1951. гоодине на основу совјетиског̄ модела: сіиеиеене канди-

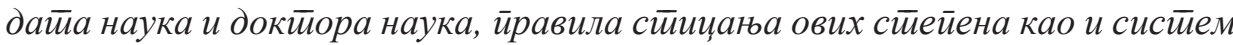
научних и истираживачких класификација, корищћених јощи и дан данас.

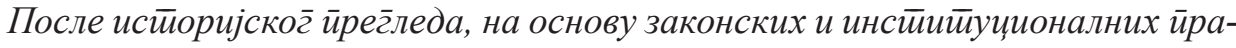
вила, анализира рег̄улисање академских стиеиена и звања, у иериоду йосле йромене режима. Посебну йажну иосвећује иситраживању системе неоихходних

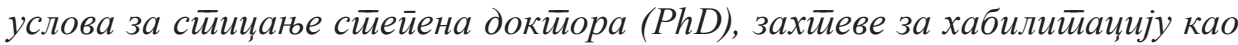
научну квалификачију, иравила за стиицање зваға докӣора Мађарске академије наука, као замену сиеиеиена докӣора наука, као и услове неойходне да би неко йостиао редовни и дойисни члан Академије.

Кључне речи: академски стеиеиени; мађарска иравна наука; CSc; DSc; PhD; хабилийација; Мађарска академија наука.

Датум пријема рада: 12.12.2016. 